\title{
Personal Professional Development Efforts Scale for Middle School Mathematics Teachers: An Adaptation Study
}

\author{
M. Zafer Balbă
}

Assoc. Prof., Eskisehir Osmangazi University, Turkey, zbalbag@ogu.edu.tr

\section{Kürşat Yenilmez}

Prof., Eskisehir Osmangazi University, Turkey, kyenilmez@ogu.edu.tr

\section{Melih Turgut}

Asst. Prof., Eskisehir Osmangazi University, Turkey, mturgut@ogu.edu.tr

This study aimed at adapting the personal professional development efforts scale developed for science and technology teachers to be applied for middle school mathematics teachers. For this purpose, first of all, the items of the original scale were adjusted for the middle school mathematics teachers by a team of experts. Data obtained by the new scale format from the middle school mathematics teachers working in different regions of Turkey $(\mathrm{N}=117)$ were subjected to exploratory (principal components method) and confirmatory (primary and secondary level) factor analyses. At the end of these analyses, it was concluded that the scale with six factors does not originally remain the same and confirms the scale with five factors. Based on the reliability analysis of the final version, it was noted that Cronbach's Alpha value of the whole scale is .913. Accordingly, it was observed that the scale with five factors is applicable in terms of a study on the levels of personal professional development efforts for middle school mathematics teachers.

Keywords: middle school, mathematics teachers, personal professional development efforts, scale development, professional development, personal efforts

\section{INTRODUCTION}

In the world of fast-growing information and technology sectors, the sound steps to be taken in the education and training field are essential for the conduct of exact future plans in order to achieve the specific targets to train new generations keeping up with this age and to raise the quality of education. The most important step is training the teachers. Teachers have to keep track of the current developments and use the knowledge and skills they acquired from the faculty of education while performing their

Citation: Balbağ, M. Z., Yenilmez, K., \& Turgut, M. (2017). Personal Professional Development Efforts Scale for Middle School Mathematics Teachers: An Adaptation Study. International Journal of Instruction, 10(4), 325-342. https://doi.org/10.12973/iji.2017.10419a 
profession. Within that respect, this development is based on the fact that the teachers should improve themselves professionally.

Furthermore, teachers should ask themselves these questions: "Am I good as a field teacher?", "Can I sufficiently improve myself?", “Am I successful at my job?”, "Do my students feel that I am qualified enough for my job?", "What should I do to improve myself more as a teacher?". An ideal teacher can ask himself/herself these questions, do what is necessary to behave accordingly and is decisive to raise awareness in his profession. Teachers should comply with the changes and developments in their educational system, keep up-to-date with the developments in education-training field on an ongoing basis, and perform activities to improve their personal professional development in the field once they start to work as a teacher. Moreover, teachers have to keep track of the education-training activities performed in developed countries in terms of science and technology despite the differences in educational systems. This issue is of high importance to increase the quality of education and training in these countries. Education, which is the training process of people for a particular aim can make differences in individual personality. These differences stem from the knowledge, skills, attitudes and values obtained in this process. Today, schools constitute the vital part of the educational process (Fidan, 2012). Education and training started at birth continue until death and have an impact on our success, happiness and relations. Throughout the civilizations, people have considered learning and teaching significant and necessary measures have been taken to that end (Barutçigil, 2002).

A teacher who is defined as "a person teaching knowledge" is one of the most important units of education-training process. Teachers are key factors in the qualitative development of education systems. They also have a crucial role in the success or failure of the educational program reform (Banaz-Sierra, Diaz-Correa, Mellado \& Ruiz, 2008). Main objective of training teachers is to train qualified teachers. Qualified teachers have the essential knowledge and skills in the profession, field and general knowledge (Cobb, Darling Hammond and Murangi, 1995). The aim of the teaching profession is to introduce a good, creative, constructive and helpful person for himself/herself, family and friends (Tekışık, 1987). The students take their teachers as a model especially during the adolescence. The students are impressed by a decisive, hard-working, wellgroomed and qualified teacher at school; often adapt a positive attitude towards the course of such a teacher and become successful. Bearing this in mind, teachers should try to develop both their knowledge level and personal background (Çelikten, Şanal and Yeni, 2005). If teachers do not adapt themselves to developments; in other words, if they do not support and maintain life-long learning, they will face with difficulties in many aspects (Kisakürek, 2003).

Therefore, professional development of teachers is as important as basic training of teachers. A good trainer should have a sufficient level of knowledge about his/her profession; have competence in training; comprehend the educational system and its policies; reach the competence level of entirety between his/her own status within the system and other ranks (Özden, 2010). Teachers act as a guide in terms of the goals of a state as well as expectations and level of the society. Teachers should cover up their 
deficiency and have the essential competences in order to train their students for the society and the future.

As for Bandura (1993), competence is the individual belief to perform one's duty. Teachers with a high level of competence have higher professional developments. Özden (2001) states that the primary objective of professional development is to keep up-to-date with and learn the necessary qualifications and develop the knowledge, skills and behaviours of the profession so as to perform one's duty better. Duttweiler (1989) defines the professional development of teachers as an activity or a process aiming at positive changes in knowledge, skills and behaviours. Ganser (2002) notes that professional development includes two types of experience: formal experiences (participation in workshops, meetings or monitoring activities etc.) and informal experiences (reading publications on the profession, watching television programs on academic discipline etc.). Cros, Duthilleul, Cox and Kantasalmi (2004) concluded that the professional development of teachers has a complex structure in different countries and made an evaluation as follows:

- The training of teachers with a changing content due to the developments in information and researches but without a concrete and theoretical basis is out of question.

- The training of teachers cannot be separated from practice. We learn as we take part in practices and the course is the location where this profession is learned although the profession of teaching is increasingly regarded as knowledgeoriented.

- The training of teachers cannot be considered stable. The profession of teaching is at the focus of social changes. Therefore, teachers should teach their students how to learn during their lifetime and should continue to improve themselves and conduct improving activities throughout their career (as cited in Bayram, 2010).

Accordingly, it is of high importance for the future of a country that all teachers from each field should improve themselves in their field based on the profession. Thus, it is likely to train good teachers based on the quality of the educational system (Wössmann, 2002; Nye et al., 2004; OECD, 2005; Hanushek, 2008). It is clear that teachers working in different fields in Turkey have particular studies on personal professional development (Yıldız, 2006; Ünal, 2010; Koç, 2010; Bayram, 2010; Yıldızlı, 2011; Bilgin and Balbağ, 2016). In his study titled "Identification of Technological Competency Levels of Science and Technology Teachers", Ünal (2010) found out that male teachers resort to technology more often than their female counterparts. Moreover, Ünal (2010) stated that male teachers are more prone to benefiting from technology. It was concluded that teachers with 1-5-year experience benefit from the available technological devices more often, but they are less interested in new technological developments when they gain more professional experience. Apart from the existing researches in the literature, the aim of this research was to adapt the personal professional development efforts scale developed for science and technology teachers to be applied for middle school mathematics teachers to picture out and compare those efforts. 


\section{LITERATURE REVIEW}

There are several studies in the literature focusing on professional development of teachers. For instance, in his study titled "Competences of Religion and Ethics Teacher", Koç (2010) tried to determine how religion and ethics teachers perceive their professional competences. Accordingly, teachers find themselves eligible in terms of basic qualifications such as special field knowledge, pedagogical formation and general knowledge as well as their performance in practices. However, teachers generally feel that they use new techniques on measurement and evaluation on average, but young teachers are a bit more qualified to use these techniques. It is evident that gender, teaching level and the graduation program of the teachers do not play a key role in their personal and professional development; however, more senior teachers are more qualified within that respect. It was observed that teachers are less qualified in keeping up with the advances and developments on their profession and fields; being open to changes; improving themselves and taking responsibility in social relations and activities apart from the school.

Bayram (2010) conducted a comparative educational research in his study. In the research, professional development programs of science and physics teachers in Turkey were compared with the professional development programs of science and physics teachers in more developed countries such as the USA, Japan, Britain and Australia. Accordingly, professional development in Turkey is applied more centrally. In other countries, there are various activities ensuring the teachers to follow the developments on teaching; update and enhance their knowledge in their fields. In some states of the USA, practices differ from the others as science and physics teachers have to attend professional development programs in order to renew their licenses. In these countries, teachers work in cooperation with their colleagues and share their experiences with each other. It is sure that this cooperation will be fruitful and important. In the light of the data obtained from these researches, it is evident that the teachers in Turkey are less qualified in terms of their training and personal and professional development especially after they start practising their professions.

In their study titled "Perceptions of Form Teachers with Different Professional Development about Professional Competence" Coşkun et al. (2010) tried to determine the perceptions on professional competence of 18 form teachers with various levels of seniority. Accordingly, teachers with various levels of seniority have different definitions of teaching competence in general and competence in special field as form teaching: form teachers with a teaching experience of 1 to 5 years consider teaching competence as appointment or passing the KPSS (Public Personnel Selection Examination of Turkey) exam; teachers with a teaching experience of 6 to 10 years consider teaching competence as having the necessary knowledge and qualifications on their profession and being able to transfer this knowledge and experience to the class; teachers with a teaching experience of 11 years and more consider teaching competence as professional experience and being a model teacher. Moreover, with respect to the methods to improve the professional competence, teachers with a teaching experience of 1 to 5 years stated that they do their best to increase their professional competence level; 
they contact with their colleagues and participate in in-service courses. However, teachers with a teaching experience of 6 years and more noted that they tried to perform some professional activities and to follow new approaches. This may stem from the fact that teachers with a high level of professional experience feel higher levels of burnout.

In his study titled "A research on the professional self-improvement levels of gym and sports teachers, Yildiz (2006) conducted a research on the professional selfimprovement levels of gym teachers working in Mersin. According to this research, teachers are not qualified enough to use technology. It was noted that teachers are in need of in-service courses. However, more senior teachers often benefit from visual and audial teaching technologies during their courses. Gym teachers are eligible enough to follow periodical publications on their field and take part in the scientific activities. Teachers are in positive and participative touch with their group. Nevertheless, the administration and inspectors should back up the teachers for professional development and raise consciousness among the teachers on post-graduate programs in order to keep up with the current developments. Moreover, this research emphasized that MoNE, General Directorate of Youth and Sports and universities should collaborate to encourage gym teachers, improve their social and personal characteristics and enhance their professional development.

Yildızlı (2011) conducted a research on professional developments of primary school mathematics teachers: The post-graduate thesis titled "Competency Perceptions of Primary School Mathematics Teachers In Terms of General Teaching Behaviours (A Sample on the province of Ankara)" focuses on whether primary schools mathematics teachers find themselves qualified enough in terms of general teaching behaviours and whether the variables such as gender, seniority and graduation faculty differ based on the competency levels of teachers. According to the findings of this research, teachers usually find themselves qualified enough within that respect. There is not a significant difference among teachers with respect to gender and seniority, while this difference is clear in terms of the graduation faculty variable.

\section{Purpose of the Study}

Although there are research studies on the personal professional development of teachers, the number of these researches is insufficient for teachers who are required to constantly improve themselves due to the teaching programs changing in line with the development in the countries and more researches are needed, accordingly. This study is of high importance to determine the current status of personal professional development levels of middle school mathematics teachers; to take the necessary measures and to be confident about the future. This study includes an adaptation of the scale called Personal Professional Development Efforts Scale (PPDES) for science and technology teachers in their field developed by Bilgin and Balbağ (2016) for science and technology teachers working in Turkey to the middle school mathematics teachers. This adapted scale may be examined based on several variables. Therefore, this study is of high importance. 


\section{METHOD}

\section{Research Design}

In this study, the scale developed to determine personal professional development efforts of science and technology teachers in their field was adapted to the middle school mathematics teachers in line with the specified objective. Along this direction, some specific steps were followed: $(i)$ the items underwent expert analysis to ensure adaptation of the items for middle school mathematics teachers' professional development and Turkish language structure; (ii) pilot studies with mathematics education master students who work as mathematics teachers were carried out; and then (iii) an exploratory factor analysis was employed to check whether original factor structure remains. As the next step, (iv) a (2-step) confirmatory factor analysis to assess the model constituted by the factors was employed. Finally, $(v)$ reliability analysis was conducted for each factor and the entire scale.

\section{Participants}

In the present study, 117 in-service middle school mathematics teachers (69 females, 48 males) working in different regions of Turkey volunteered to participate in the study. The mean teaching experience for the participants was $5.1(\mathrm{SD}=1.3)$ years ranging from 1 to 14 years. Two mathematics education master students working as teachers at public middle schools in a western city of Turkey participated in the pilot study just to ensure that the items were easy to read, comprehensible and suitable for their professional development context.

\section{Instrument}

The original instrument, PPDES, was developed by Bilgin and Balbağ (2016) to assess science and technology teachers' personal professional development efforts related to their profession. PPDES has a 5-point Likert structure and 6 factors and 27 items, which was obtained through principal components analysis with Varimax rotation method. Factors of the scale are educational and cultural knowledge, specialisation, following scientific and technological developments, following curriculum, following media and publications. Internal consistency of the factors ranged from .64 to 83, and the entire scale's Cronbach's alpha was found to be .82 .

\section{Procedure and Data Analysis}

First of all, expressions specific to the education training of science and technology in the items of the scale were adapted to the context of middle school mathematics education training by a group of mathematics education experts. The experts checked each item following such criterions: (i) the item is directly suitable for mathematics education context, (ii) the item should be amended with respect to mathematics education context, (iii) the item does not belong to mathematics education context. Afterwards, a Turkish language expert checked all items to ensure whether items measured what they were intended to do. Moreover, after language check, we requested two mathematics education master students to read each item and explain what they understood. Based on all feedback, some items were revised. The final scale was 
transformed into an online questionnaire form and disseminated to in-service middle school mathematics teachers to fill the items. The data obtained from 117 middle school mathematics teachers' responses were analysed through SPSS 21 software package within principal components analysis to elaborate the scale's factor structure. Next, in order to explore the models constituted by the factors, LISREL 8.72 software package was used.

\section{FINDINGS}

Original scale composed of 6 factors and 27 items; and Explanatory Factor Analysis (EFA) (Principal Components Analysis) and Confirmatory Factor Analysis (CFA) were applied to the data collected from a group of 117 people to examine whether the scale applied maintains its factor structure. In order to check the suitability of the group consisting of 117 people to factor analysis, Kaiser-Meyer-Olkin (KMO) and Bartlett's test of sphericity value and level of significance were analysed using SPSS 21.0 software. Table 1 displays the related results.

Table 1

Results of KMO and Bartlett's Test of Sphericity

\begin{tabular}{ll}
\hline KMO & .849 \\
\hline Bartlett's Test of Sphericity —Chi-Square & 1641.406 \\
\hline $\mathrm{df}$ & 351 \\
\hline Level of Significance & .000 \\
\hline
\end{tabular}

According to Table 1, it was observed that chi-square value is significant at .01, and at the same time, KMO value is sufficient to realize factor analysis, $X^{2}=1641.406, \mathrm{df}=351$, p<.001 (Çokluk et al., 2012, p. 207) and therefore, the data implies a multivariate normal distribution. For the next step, EFA was realized through SPSS 21.0 software. Firstly, common variance values of the data were examined. Table 2 addresses these results.

Table 2

EFA Common Variance Values of the Items

\begin{tabular}{llll}
\hline Item No & Variance Value & Item No & Variance Value \\
\hline 1 & .549 & 15 & .804 \\
\hline 2 & .764 & 16 & .743 \\
\hline 3 & .549 & 17 & .375 \\
\hline 4 & .666 & 18 & .617 \\
\hline 5 & .668 & 19 & .739 \\
\hline 6 & .533 & 20 & .753 \\
\hline 7 & .655 & 21 & .585 \\
\hline 8 & .635 & 22 & .569 \\
\hline 9 & .698 & 23 & .700 \\
\hline 10 & .598 & 24 & .704 \\
\hline 11 & .527 & 25 & .666 \\
\hline 12 & .732 & 26 & .635 \\
\hline 13 & .739 & 27 & .636 \\
\hline 14 & .803 & & \\
\hline
\end{tabular}


In Table 2, common variance value of only 17 th item is slightly low, while the common variance values of all other items vary between high values. Based on these values, it was considered that analyses might continue with all items. Software proposed 6 factors, as in the original version of the scale, and the total variance explained by these 6 factors is $65.337 \%$. However, the absence of items in some factors and overlapping items revealed the need for addressing scree plot. This scree plot is presented in Figure 1.

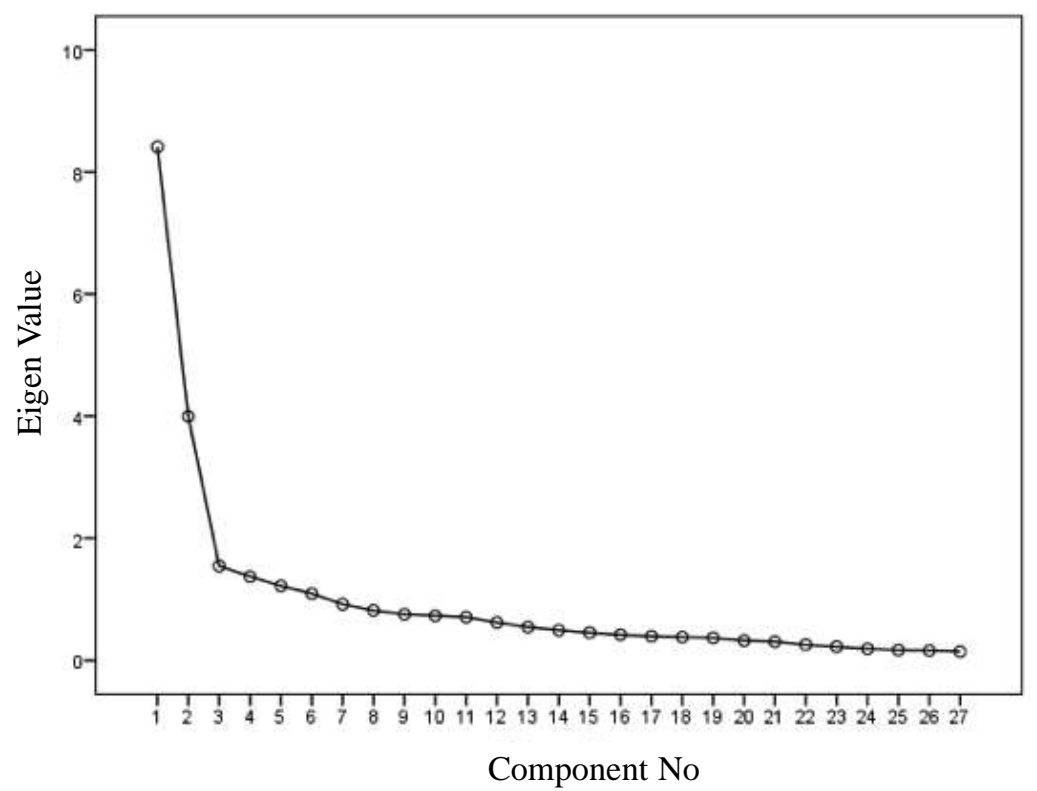

Figure 1

The scree plot

When Figure 1 is examined, it is seen that scree plot refracts after the 6th component. In a sense, this gives the clue that the scale may have a five-factor structure. Considering that the original version of the scale has 6 factors and in view of Figure 1 (five-factor structure), factor structure of the scale was examined through Varimax rotation method for two different cases (factor loading values were taken as .40 and above). It was observed that in 6-factor structure, some items are overlapping; and items with the same significance (19 and 20th items) gather under one item by them. Bearing in mind that this factor titled "Keeping Up-to-date with the Media and Publications" may be related to the factor titled "Keeping Up-to-date with Scientific Developments", it was thought that the scale might have a five-factor structure. It was observed that the five-factor structure explains $61.289 \%$ of the total variance, and factors titled "Keeping Up-to-date with Media and Publications" and "Keeping Up-to-date with Scientific Developments" gather together, as estimated. Common variance values of the factors and item loadings related to the rotation process (before and after) of the five-factor structure are presented in Table 3. 
Table 3

Factor Loadings of the Five-Factor Structure and Total Variance Explained

\begin{tabular}{|c|c|c|c|c|c|c|c|}
\hline \multirow{2}{*}{ Item No } & \multirow{2}{*}{$\begin{array}{l}\text { Factor } \\
\text { Loading }\end{array}$} & \multicolumn{5}{|c|}{ Factor loadings after rotation } & \multirow{2}{*}{$\begin{array}{c}\text { Factor } \\
\text { Common } \\
\text { Variance }\end{array}$} \\
\hline & & Factor 1 & Factor 2 & Factor 3 & Factor 4 & Factor 5 & \\
\hline 24 & .694 & .793 & & & & & .704 \\
\hline 23 & .699 & .786 & & & & & .700 \\
\hline 26 & 609 & .691 & & & & & .635 \\
\hline 27 & .596 & .663 & & & & & .636 \\
\hline 25 & .627 & .641 & & & & & .666 \\
\hline 21 & .581 & .525 & & & & & .585 \\
\hline 18 & .606 & .449 & & & & & .617 \\
\hline 2 & .673 & & .761 & & & & .764 \\
\hline 5 & .648 & & .703 & & & & .668 \\
\hline 6 & .528 & & .665 & & & & .533 \\
\hline 1 & .515 & & .652 & & & & .549 \\
\hline 3 & .526 & & .622 & & & & .549 \\
\hline 4 & .362 & & .490 & & & & .666 \\
\hline 15 & .802 & & & .870 & & & .804 \\
\hline 16 & .662 & & & .680 & & & .743 \\
\hline 7 & .643 & & & .664 & & & .655 \\
\hline 22 & .557 & & & .497 & & & .569 \\
\hline 17 & .372 & & & .486 & & & .375 \\
\hline 14 & .803 & & & & .828 & & .803 \\
\hline 13 & .735 & & & & .810 & & .739 \\
\hline 12 & .689 & & & & .737 & & .732 \\
\hline 11 & .504 & & & & .451 & & .527 \\
\hline 19 & .708 & & & & & .704 & .739 \\
\hline 20 & .688 & & & & & .682 & .753 \\
\hline 10 & .517 & & & & & .613 & .598 \\
\hline 9 & .626 & & & & & .579 & .698 \\
\hline 8 & .577 & & & & & .567 & .635 \\
\hline
\end{tabular}

Based on Table 3, it was decided that the new form of the scale applied to the middle school mathematics teachers had a 5-factor structure, and factor titles were re-organized. Although factor titles were parallel, the corresponding position of the items in the factor structure was changed. As in the original version, the first factor was titled as "Specialization" (SP), second factor as "Educational and Cultural Development" (ECD), third factor as "Professional Communication with the Shareholders" (PCS), fourth factor as "Utilization of Information and Communication Technologies" (UICT), and fifth factor as "Keeping Up-to-date with Related Media and Publications" (KURMP). At this point, the variance explained by the sub-factor of specialization clarified $15.271 \%$ of the total variance; and the sub-factor of Educational and Cultural Development explained $14.184 \%$ of the total variance. Similarly, the sub-factor of Professional Communication with the Shareholders explained $10.742 \%$ of the total variance while the sub-factor of Utilization of Information and Communication Technologies explained $10.623 \%$ and the sub-factor of Keeping Up-to-date with Related Media and Publications explained $10.469 \%$. Moreover, loading values of the factors varied between .449-.793, .490-.761, $.486-.870, .451-.820, .567-.704$, respectively. Correlations of the sub-factors and the whole scale are presented in the below table (Table 4). 
Table 4

Correlations Between the Factors and the Entire Scale

\begin{tabular}{ccccccc}
\hline Factor Title & S & ECD & PCS & UICT & KURMP & Total \\
\hline SP & - & & & & & \\
\hline ECD & $.669^{* *}$ & - & & & & \\
\hline PCS & $.298^{* *}$ & $.364^{* *}$ & - & & & \\
\hline UICT & $.304^{* *}$ & $.405^{* *}$ & $.550^{* *}$ & - & & \\
\hline KURMP & $.343^{* *}$ & $.339^{* *}$ & $.587^{* *}$ & $.575^{* *}$ & - & \\
\hline Total & $.801^{* *}$ & $.801^{* *}$ & $.689^{* *}$ & $.681^{* *}$ & $.702^{* *}$ & - \\
\hline
\end{tabular}

In order to evaluate the model formed by the obtained factors, CFA (first and second level) was applied. To this end, the indices taken into account are: (Çelik and Y1lmaz, 2013; Çokluk et al., 2012): $X^{2} / d f$, Comparative Fit Index (CFI), Normed Fit Index (NFI), NonNormed Fit Index (NNFI), Root Mean Square Error of Approximation (RMSEA). In the light of these values, first level CFA results are presented as follows (Figure 2):

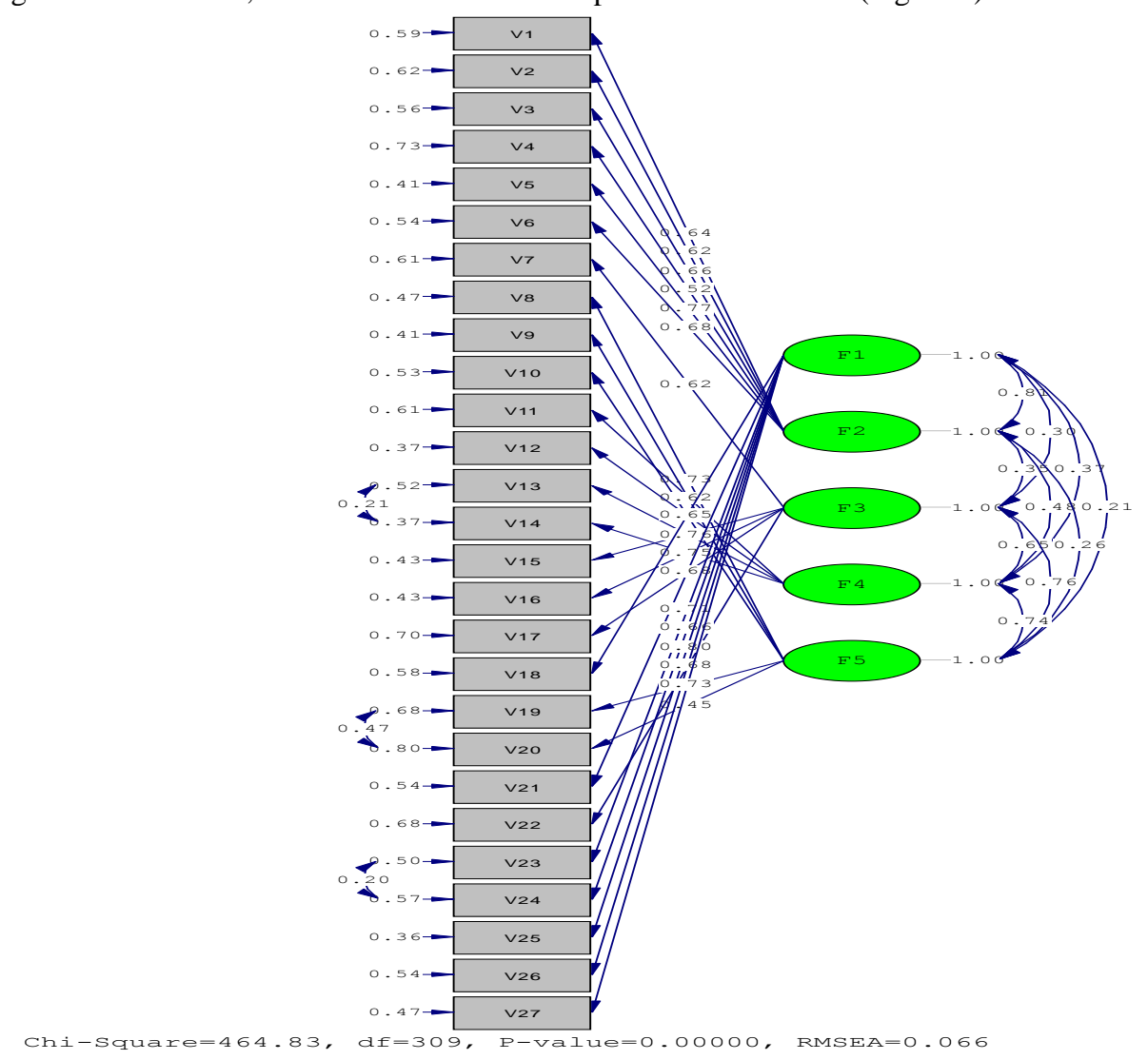

Figure 2

First level CFA results

International Journal of Instruction, October $2017 \bullet$ Vol.10, No.4 
As a result of the analysis, the index values obtained are as follows: $X^{2} / \mathrm{df}=1.504$, $\mathrm{CFI}=0.95, \mathrm{NFI}=0.88, \mathrm{NNFI}=0.95, \mathrm{RMSEA}=0.06$. It was found out that the first two and last index values are within the acceptable range (Çelik and Yılmaz, 2013). With the aim of analysing the model formed together by the five factors obtained, second level factor analysis was applied. Figure 3 represents the model and loading values.

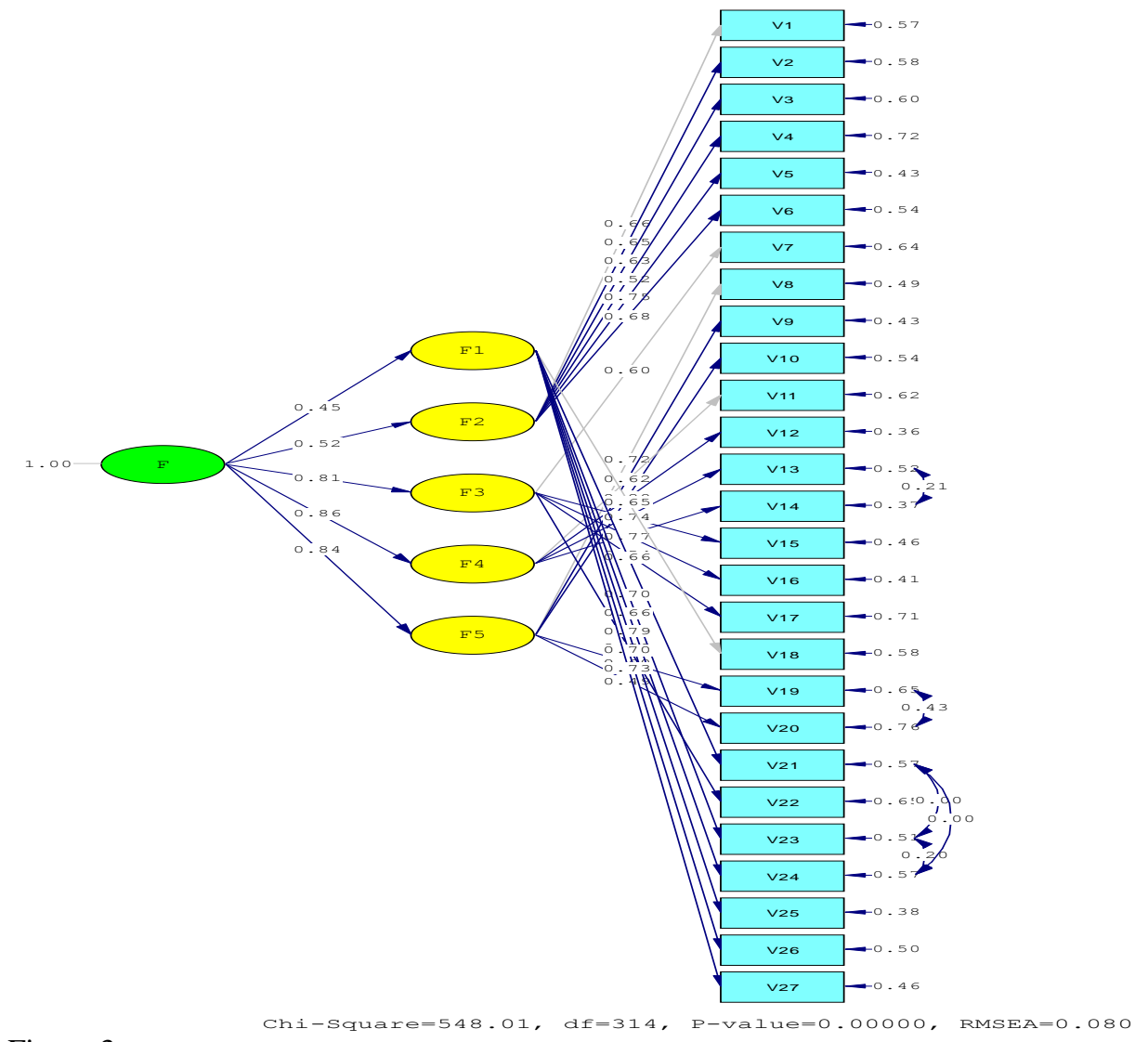

Figure 3

Second Level CFA results

Result of the second level factor analysis is as follows: $\mathrm{X}^{2} / \mathrm{df}=1.745, \mathrm{CFI}=0.94$, $\mathrm{NFI}=0.87, \mathrm{NNFI}=0.93$, RMSEA $=0.08$. Similar to the CFA at first level, it was found out that first two and the last index values are within the acceptable range.

With respect to reliability analyses, it was found out that the Cronbach Alfa value of the whole scale is .913 , while the values of the sub-factors are .874 for the first factor, .807 for the second factor, .773 for the third factor, .829 for the fourth factor, and .780 for the fifth factor. Through the Split-half method, the first half was determined as .846, and the second half as .871 (Guttman Split value .810, Spearman-Brown value .817). The final 
form of the new version of the scale whose validity and reliability was confirmed is presented in ANNEX-1.

\section{CONCLUSION AND SUGGESTIONS}

This study attempted to adapt the scale developed by Bilgin and Balbağ (2016) in an aim to analyse the personal professional development efforts of science and technology teachers in their fields to middle school mathematics teachers. Accordingly, the subdimension and some items of the adapted scale were changed. It was determined that unlike the former scale, the personal professional development efforts scale for middle school mathematics teachers consisted of five sub-dimensions, namely specialization, educational and cultural background, professional communication with the shareholders, utilization of information and communication technologies, and keeping up-to-date with related media and publications.

According to the results of the analysis, the strongest factor in relation to the whole scale was the utilization of information and communication technologies, while the weakest was specialization (Figure 3). Based on these results, it was clear that the most important factor on the opinions of middle school mathematics teachers about their personal professional developments was the utilization of information and communication technologies, while the weakest was the specialization in their fields. This result may be justified with the efforts for the use of information and communication technologies in classrooms, observed in the recent projects carried out by the Ministry of Education of Turkey. Adapted scale has a parallel form with its original version and enables the analysis of the relation between the personal professional development efforts ideally expected from teachers and their current factual personal professional development efforts.

Thanks to this study, the research data obtained through the application of this adapted scale would contribute to the field; and depending on the results of the research, negative and deficient aspects would be eliminated through the realization of concrete activities or regulations, enhancing the personal professional development efforts of middle school mathematical teachers in Turkey. This study is crucial in terms of revealing the current condition of the personal professional development status of middle school mathematics teachers in their fields and thus, in terms of taking reformatory measures for the future generations. Accordingly, the literature includes studies pointing that the branch teachers do not consider themselves self-sufficient with regard to their personal and professional developments (Altun and Cengiz, 2012; Gürbüz et al., 2013; Şahin Taşkın and Hacıömeroğlu, 2010). As a result of this research, a reliable and valid scale to determine the personal and professional developments of mathematics teachers in their fields was developed, and this can be used in related future studies in the field of mathematics. Moreover, this study pointed that the scale may also be applied in fields under other disciplines, and will evidently evoke ideas in building other scales.

\section{ACKNOWLEDGEMENT}

This study was supported by Scientific Research Projects Commission of Eskişehir Osmangazi University (ESOGU-BAP) (project no: 201521031). 


\section{REFERENCES}

Altun, T., \& Cengiz, E. (2012). İlköğretim II. Kademe branş öğretmenlerinin mesleki gelişim firsatları hakkındaki görüşleri. International Online Journal of Educational Sciences, 4(3), 672-690.

Banaz-Sierra, C., Diaz-Correa, L., Mellado, V., \& Ruiz, C. (2008). The effect of secondary education teachers' involvement in an action_research program on their students' alternative ideas on energy. Journal of Physics Teacher Education Online, 5(1), 20-31.

Bandura, A. (1993). Perceived self-efficacy in cognitive development and functioning. Educational Psychologist, 28(2), 117-148.

Barutçugil, İ. (2002). Eğiticinin eğitimi. İstanbul: Kariyer.

Bayram, D. (2010). Türkiye, ABD, Japonya, Ingiltere ve Avustralya'da fen ve fizik ögretmenlerine yönelik mesleki gelişim programlarının karşılaştırılması (Unpublished doctoral thesis), Ankara University, Ankara.

Bilgin, A., \& Balbağ, M. Z. (2016). Personal professional development efforts scale for science and technology teachers regarding their fields. Acta Didactica Napocensia, 9(2), $67-78$.

Cobb, V., L., Darling-Hammond, L., \& Murangi, K. (1995). Teacher preparation and professional development in APEC members: An overview of policy and practice. In L. Darling-Hammond \& V. L. Cobb, (Ed), Teacher preparation and professional development in APEC members: A comparative study (pp. 1-16). Washington, DC: U.S. Department of Education.

Coşkun, K., Metin, M., Birişci, S., \& Kaleli Yılmaz, G. (2010). Farklı mesleki deneyime sahip sınıf ögretmenlerinin mesleki yeterlilik ile ilgili alglamalarl. International Conference on New Trends in Education and Their Implications, Antalya.

Cros, F., Duthilleul, Y., Cox, C., \& Kantasalmi, K. (2004). Attracting, developing and retaining effective teachers. Country Note: Spain-OECD

Çelik, H. E., \& Yılmaz, V. (2013). LISREL 9.1 ile yapısal eşitlik modellemesi. Ankara: An1.

Çelikten, M., Şanal, M., \& Yeni, Y. (2005). Öğretmenlik mesleği ve özellikleri. Erciyes Üniversitesi, Sosyal Bilimler Enstitüsü Dergisi, 19, 207-237.

Çokluk, Ö., Şekercioğlu, G., \& Büyüköztürk, Ş. (2012). Sosyal bilimler için çok değişkenli istatistik SPSS ve LISREL uygulamalart. Ankara: Pegem.

Duttweiler, P. C. (1989). Components of an effective professional development program. Journal of Staff Development, 10(2), 2-6.

Fidan, N. (2012). Okulda öğrenme ve ögrretme. Ankara: Pegem. 
Ganser, T. (2002). The new teacher mentors: Four trends that are changing the look of mentoring programs for new teachers. American School Board Journal, 189(12), 25-27.

Gürbüz, R., Erdem, E., \& Gülburnu, M. (2013). Sınıf öğretmenlerinin matematik yeterliklerini etkileyen faktörlerin incelenmesi. Ahi Evran Üniversitesi Kırşehir Ĕgitim Fakültesi Dergisi, 14(2), 255-272.

Hanushek, E. A. (2008). The Economic Benefits of Improved Teacher Quality. In N. C. Soguel \& P. Jaccard (Ed), Governance and Performance of Education Systems (pp. 107-135). Springer, Netherlands.

Kısakürek, M. A. (2003). 'Eleştirel Çağrışımlar ve Öğrenme', Öğrenmeyi Öğrenme Etkinlikleri, 17-18 Kasım 2003, Türkiye Zekâ Vakfı ve Talim Terbiye Kurulu Başkanlığı, ODTÜ Kültür ve Kongre Merkezi, Ankara.

Koç, A. (2010). Din kültürü ve ahlak bilgisi öğretmenlerinin yeterlilikleri. Değerler Ĕgitimi Dergisi, 8(19), 107-149.

Nye, B., Konstantopoulos, S., \& Hedges, L. V. (2004). How large are teacher effects? Educational Evaluation and Policy Analysis, 26, 237-257.

OECD (2005). Teachers matter. Attracting, developing and retaining effective teachers. Paris: OECD.

Özden, M. C. (2001). Bireysel kariyer yönetimi-profesyonelin el kitabı. Ankara: Ümit.

Özden, Y. (2010). Öğrenme ve ögretme. Ankara: Pegem.

Şahin Taşkın, Ç., \& Hacıömeroğlu, G. (2010). Meslek bilgisi derslerinin öğretmen adaylarının profesyonel gelişimindeki önemi. Pamukkale Üniversitesi Ĕ̆itim Fakültesi Dergisi, 28(2), 165-174.

Tekışı, H. H. (1987). Türkiye'de öğretmenlik mesleği ve sorunları. Hacettepe Ĕ̆itim Fakültesi Dergisi, 2(1), 24-33.

Ünal, Ö. A. (2010). Fen ve teknoloji öğretmenlerinin teknoloji yeterlilik düzeylerinin belirlenmesi (Hatay ili örneği). (Unpublished master thesis). Eskişehir Osmangazi Üniversitesi, Eskişehir.

Yıldız, S. (2006). Beden ĕgitimi ve spor öğretmenlerinin meslekte kendini geliştirme düzeylerinin incelenmesi (Master thesis). Mersin Üniversitesi, Mersin.

Yıldızlı, H. (2011). Illköğretim matematik ögretmenlerinin genel öğretmenlik davranışları açısından kendilerine yönelik yeterlilik algıları (Ankara ili örneği), (Unpublished master thesis). Selçuk Üniversitesi, Konya.

Wössmann, L. (2002). Schooling and the quality of human capital. Berlin: Springer. 


\section{ANNEX-1}

Personal Professional Development Efforts Scale for Middle School Mathematics

\section{Teachers}

In answering the questions, insert the phrase: "a good mathematics teacher" to the beginning of the sentence. Please mark only one of the following options: "Always", "Often", "Sometimes", "Rarely" and

\begin{tabular}{|c|c|c|c|c|c|c|c|c|c|c|}
\hline \multicolumn{6}{|c|}{$\begin{array}{l}\text { IDEALLY } \\
\text { (What do you expect ideally?) }\end{array}$} & \multicolumn{5}{|c|}{$\begin{array}{r}\text { PERSONALLY } \\
\text { (How often do you practice?) }\end{array}$} \\
\hline $\begin{array}{l}\stackrel{\infty}{3} \\
\frac{3}{4}\end{array}$ & $\stackrel{\Xi}{0}$ & 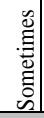 & 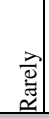 & $\begin{array}{c}\overrightarrow{0} \\
\grave{0} \\
\end{array}$ & A Good Mathematics Teacher; & 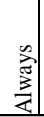 & $\underset{\frac{\Xi}{2}}{0}$ & $\begin{array}{c}0 \\
\stackrel{0}{\Xi} \\
. \\
0 \\
0 \\
0 \\
0\end{array}$ & 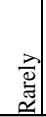 & : \\
\hline \multicolumn{11}{|c|}{ Specialization: } \\
\hline & & & & & $\begin{array}{l}\text { 1. should exchange/I exchange opinions about their field of } \\
\text { work, with the academicians. }\end{array}$ & & & & & \\
\hline & & & & & 2. should invite/I invite national field specialists to school. & & & & & \\
\hline & & & & & 3. should invite/I invite foreign field specialists to school & & & & & \\
\hline & & & & & $\begin{array}{l}\text { 4. should take part/ I take part in scientific meetings } \\
\text { (congress, seminars, conferences, etc.) in his/her field of work, as a } \\
\text { speaker. }\end{array}$ & & & & & \\
\hline & & & & & $\begin{array}{l}\text { 5. should participate/I participate in the field related } \\
\text { contests among teachers (such as "Teachers' Production") }\end{array}$ & & & & & \\
\hline & & & & & $\begin{array}{l}\text { 6. should participate/I participate in Lifelong Learning } \\
\text { programmers (Comenius, Leonardo da Vinci etc.) }\end{array}$ & & & & & \\
\hline & & & & & $\begin{array}{l}\text { 7. should keep up-to-date/I keep up-to-date with scientific } \\
\text { periodicals about his/her field. }\end{array}$ & & & & & \\
\hline \multicolumn{11}{|c|}{ Educational and Cultural Development: } \\
\hline & & & & & $\begin{array}{l}\text { 8. should visit/I visit places such as exhibitions, museums, } \\
\text { science centers related to his/her/my field. }\end{array}$ & & & & & \\
\hline & & & & & 9. should read/ I reads field related books. & & & & & \\
\hline & & & & & $\begin{array}{l}\text { 10. should participate/I participate in field related in-service } \\
\text { trainings. }\end{array}$ & & & & & \\
\hline & & & & & $\begin{array}{l}\text { 11. should participate/I participate in field related } \\
\text { knowledge contests, together with the students. }\end{array}$ & & & & & \\
\hline & & & & & $\begin{array}{l}\text { 12. should take part/ takes part in field related scientific } \\
\text { meetings (congress, seminars, conferences, etc.), as a participant. }\end{array}$ & & & & & \\
\hline & & & & & $\begin{array}{l}\text { 13. should attend/I attend field related trips outside the } \\
\text { school, (such as exhibitions, museums, science centers) together } \\
\text { with students. }\end{array}$ & & & & & \\
\hline \multicolumn{11}{|c|}{ Professional Communication with the Shareholders: } \\
\hline & & & & & $\begin{array}{l}\text { 14. should sign up/I sign up to web-sites, which enables } \\
\text { keeping up to date with the field related developments. }\end{array}$ & & & & & \\
\hline & & & & & $\begin{array}{l}15 \text {. should exchange/I exchange field related information } \\
\text { with the subject group teachers. }\end{array}$ & & & & & \\
\hline & & & & & $\begin{array}{l}\text { 16. should exchange/I exchange opinions with different } \\
\text { subject group teachers on field related matters. }\end{array}$ & & & & & \\
\hline & & & & & $\begin{array}{l}\text { 17. should exert/I exert effort to be well informed about the } \\
\text { acquisitions stated in the curriculum. }\end{array}$ & & & & & \\
\hline & & & & & $\begin{array}{l}\text { 18. should design/I design various experiments in parallel } \\
\text { with the field related experiments. }\end{array}$ & & & & & \\
\hline
\end{tabular}

International Journal of Instruction, October $2017 \bullet$ Vol.10, No.4 


\begin{tabular}{|l|l|l|l|l|l|l|l|l|}
\hline \multicolumn{7}{|c|}{ Utilization of Information and Communication Technologies: } \\
\hline
\end{tabular}

International Journal of Instruction, October $2017 \bullet$ Vol.10, No.4 


\section{Turkish Abstract \\ Ortaokul Matematik Öğretmenleri İçin Kişisel Mesleki Gelişim Çabaları Ölçeği: Uyum Çalışması}

$\mathrm{Bu}$ çalışma, ortaokul matematik öğretmenlerine uygulanarak bilim ve teknoloji öğretmenleri için geliştirilen kişisel mesleki gelişim çabalarının uyum sağlamasını amaçlamıştır. $\mathrm{Bu}$ amaçla, öncelikle, orijinal ölçeğin öğeleri bir uzman ekip tarafından ortaokul matematik öğretmenleri için düzeltilmiştir. Bu analizlerin sonucunda, altı faktörlü ölçeğin başlangıçta aynı kalmadığı ve beş faktörlü ölçeği doğruladığ 1 sonucuna varılmıştır. Buna göre, beş faktörlü ölçeğin ortaokul matematik öğretmenleri için kişisel mesleki gelişim çabalarının düzeyleri üzerine bir çalışma açısından geçerli olduğu görülmüştür.

Anahtar Kelimeler: ortaokul, matematik öğretmenleri, kişisel mesleki gelişim çabaları, ölçek geliştirme, mesleki gelişim, kişisel çaba

\section{French Abstract \\ Échelle d'Efforts de Développement Professionnelle Personnelle pour Professeurs de Mathématiques de Collège : une Étude d'Adaptation}

Cette étude a visé à adapter l'échelle d'efforts de développement professionnelle personnelle développée à la science et des professeurs technologiques à être appliqué pour des professeurs de mathématiques de collège. À cette fin, tout d'abord, les articles de l'échelle originale ont été ajustés pour les professeurs de mathématiques de collège par une équipe d'experts. À la fin de ces analyses, on l'a conclu que l'échelle avec six facteurs ne reste pas à l'origine le même et confirme à l'échelle avec cinq facteurs. En conséquence, il a été observé que l'échelle avec cinq facteurs est applicable en termes d'une étude sur les niveaux d'efforts de développement professionnels personnels pour des professeurs de mathématiques de collège.

Mots Clés: le collège, des professeurs de mathématiques, des efforts de développement professionnels personnels, pèse le développement, le développement professionnel, des efforts personnels

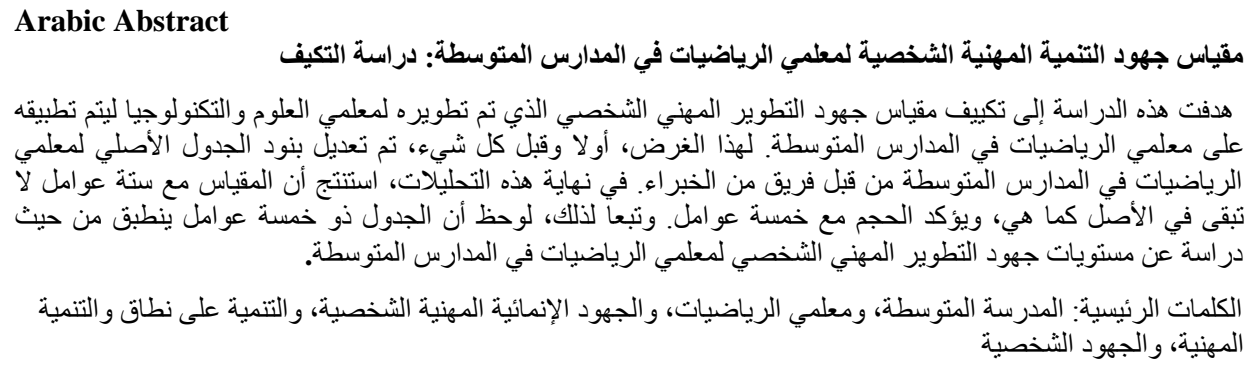




\section{German Abstract \\ Persönliche berufliche Entwicklung Bemühungen Skala für Mittelschule Mathematik Lehrer: Eine Anpassungsstudie}

Diese Studie zielte darauf ab, die persönliche berufliche Entwicklung Bemühungen Skala entwickelt für Wissenschaft und Technik Lehrer für die Mittelschule Mathematik Lehrer angewendet werden. Zu diesem Zweck wurden zunächst die Gegenstände der ursprünglichen Skala für die Mittelschulmathematiklehrer von einem Expertenteam angepasst. Am Ende dieser Analysen wurde gefolgert, dass die Skala mit sechs Faktoren ursprünglich nicht gleich bleibt und die Skala mit fünf Faktoren bestätigt. Dementsprechend wurde festgestellt, dass die Skala mit fünf Faktoren in Bezug auf eine Studie auf dem Niveau der persönlichen beruflichen Entwicklung Bemühungen für Mittelschule Mathematik Lehrer anwendbar ist.

Schlüsselwörter: mittelschule, mathematiklehrer, persönliche berufliche entwicklungsbemühungen, skalenentwicklung, berufliche entwicklung, persönliche anstrengungen

\section{Malaysian Abstract \\ Pembangunan Personal Profesional Skala Usaha untuk Guru Matematik Sekolah Menengah: Kajian Adaptasi}

Kajian ini bertujuan untuk mengadaptasi skala usaha pembangunan profesional peribadi yang dibangunkan untuk guru sains dan teknologi untuk digunakan untuk guru matematik sekolah menengah. Untuk tujuan ini, pertama sekali, item skala asal disesuaikan untuk guru matematik sekolah menengah oleh satu pasukan pakar. Pada akhir analisis ini, disimpulkan bahawa skala dengan enam faktor tidak pada asalnya tetap sama dan mengesahkan skala dengan lima faktor. Sehubungan itu, diperhatikan bahawa skala dengan lima faktor boleh digunakan dari segi kajian mengenai tahap usaha pembangunan profesional peribadi untuk guru matematik sekolah menengah.

Kata Kunci: sekolah menengah, guru matematik, usaha pembangunan profesional peribadi, pembangunan skala, pembangunan profesional, usaha peribadi

\section{Russian Abstract \\ Индивидуальная Шкала Профессиональных Навыков для Учителей Математики Средней Школы: Исследование Адаптации}

Целью данного исследования является масштабирование индивидуальных усилий по профессиональному развитию, разработанных для учителей науки и техники, которые будут применяться к учителям математики средней школы. Для этого, в первую очередь, предметы первоначальной шкалы были скорректированы для учителей математики средней школы группой экспертов. В конце этих анализов был сделан вывод о том, что шкала с шестью факторами первоначально не остается неизменной и подтверждает масштаб с пятью факторами. Соответственно, было отмечено, что шкала с пятью факторами применима с точки зрения исследования уровней личных усилий по профессиональному развитию для учителей математики средней школы.

Ключевые Слова: средняя школа, учителя математики, личные усилия по профессиональному развитию, масштабное развитие, профессиональное развитие, личные усилия 